\title{
ТРАНСФОРМАЦИЯ ИНСТРУМЕНТОВ ГОСУДАРСТВЕННОГО РЕГУЛИРОВАНИЯ СОВРЕМЕННОЙ ЭКОНОМИКИ С УЧЕТОМ ПРОТИВОРЕЧИВОСТИ ГЛОБАЛИЗАЦИОННЫХ ПРОЦЕССОВ
}

\author{
(c) 2020 Ярлыченко Алла Александровна \\ кандидат экономических наук, младший научный сотрудник кафедры логистики и управления \\ Казанский национальный исследовательский технологический университет, \\ Республика Татарстан, Казань \\ E-mail: alla.yarlychenko@mail.ru
}

В статье анализируются альтернативные подходы к трактовке содержания процессов глобализации. В ходе исследования выявлена их противоречивость и двойственный характер воздействия на направления и динамику социально-экономического развития отдельных государств и мирового хозяйства; доказано, что на рубеже XX-XXI вв. формы реализации глобализационных процессов кардинально изменяются под влиянием кризисных явлений; определено, что при сохранении взаимозависимости субъектов мирохозяйственных отношений формирование многополярного экономического пространства приводит к изменению источников конкурентного потенциала отдельных производителей и территорий их размещения. Сделан вывод, что эффективность государственного регулирования экономики определяется полнотой учета процессов глобализации и локализации. Понимание изменений в составе источников и последствий глобализационных процессов позволяет расширить представления о составе факторов социально-экономического развития современных государств.

Ключевые слова: Глобализация, локализация, мировое экономическое пространство, конкурентные преимущества, экономический и санитарный кризис, факторы экономического роста, государственное регулирование экономики.

Мировой экономический и санитарный кризис, вызванный пандемией коронавируса COVID-19, оказал влияние не только на динамику агрегированных показателей состояния экономики всех современных государств, но и стал отправной точкой для научных дискуссий относительно ключевых проблем современности. Глубина воздействия кризисных явлений на современное состояние всех сторон общественной жизни вызвала необходимость пересмотра ориентиров долгосрочного развития, что активизировало традиционные и дало начало новым направлениям научных исследований. Подобный интерес к ключевым проблемам экономической науки был обусловлен совокупностью обстоятельств, среди которых - отсутствие единых представлений о содержании эффективных инструментов антикризисного регулирования экономики, что вызвало принятие в разных странах альтернативных моделей сдерживания распространения вирусной инфекции; при- знание негативных последствий глобализации мирового экономического пространства, вызвавшей зависимость отдельных государств от импорта предметов первой необходимости, в том числе медицинских средств индивидуальной защиты; новое понимание ответственности государств за меры управляющего воздействия в условиях взаимозависимости участников мирохозяйственных отношений и др. В этих условиях особую актуальность приобретают проблемы долгосрочных ориентиров развития отдельных государств и мирового сообщества в целом с учетом глубины кризисных явлений и новых вызовов эпохи. Фундаментальность, многоуровневость и междисциплинарный характер данной проблемы обусловливает необходимость рассмотрения ее отдельных аспектов, к числу которых относится изменение содержания глобализационных процессов.

Проведенное исследование показывает, что несмотря на многочисленные работы, посвя-

\footnotetext{
* Исследование выполнено в рамках гранта Президента РФ по государственной поддержке ведущих научных школ РФ № НШ-2600.2020.6. Тема научного исследования: «Методология организации процессов ресурсосбережения в условиях цифровизации инновационных экономических систем»
} 
щенные проблемам глобализации, среди ученых отсутствует единая трактовка содержания данного термина, а также причин и последствий глобализационных процессов. В научной литературе доминирует позиция, согласно которой глобализация представляет собой атрибутивный признак современного этапа развития общества, определяемого как постиндустриальное, информационное и сетевое (У.Бек [1], М.Кастельс [3], С.Хоффман [6] и др.). В то же время распространенными являются определения, которые акцентируют внимание на отдельных аспектах глобализационных процессов, включающих усиление взаимозависимости участников мирохозяйственных отношений (М.В.Ильин [2]), качественные социальные изменения (И. Валлерстайн [10]), вектор развития современного общества (Д.Несбита [4]), интегральное условие существования человеческой цивилизации (Р.Робертсон [8]) и др. При этом отсутствует единая трактовка периода начала глобализации. Одни авторы связывают ее с периодом экспансии мировых религий (Г. Терборн [9]), другие - с эпохой становления общеевропейского рынка в Новое время (И.Валлерстайн [10]), третьи - с процессами интернационализации экономики развитых государств после Второй мировой войны (Ж.Г.Уильямсон [11]) и др. Многоаспектность процесса глобализации предопределяет междисциплинарный характер ее исследования. При этом не представляется возможным рассматривать глобализационные процессы как некий общий тренд, характеризующийся единообразием и полнотой, что создает дополнительные препятствия для их изучения и выступает предпосылкой для отрицания некоторыми исследователями гносеологического потенциала данной категории. Однако проведенное исследование фактологического материала и многочисленных работ, посвященных данной проблематике, позволяет сделать вывод о необходимости дальнейшего изучения глобализации с учетом ее противоречивости и неоднозначности. Подобный вывод обусловлен значимостью глобализационных процессов для состояния всех сторон общественной жизни в современном мире, а также их ролью в конструировании траектории развития в долгосрочном периоде.

В рамках данного исследования глобализация рассматривается как процесс качественной трансформации всех составляющих современного общества (экономических, по- литических, социальных, этических и др.) и одновременно как атрибутивная характеристика постиндустриального хозяйственного уклада, обусловленная широким внедрением информационно-коммуникационных технологий в воспроизводственный процесс, что обусловливает усиление взаимообусловленности индивидуальных и интегрированных участников мирохозяйственных отношений, универсализацию экономических законов и снижение значимости государственных границ для осуществления эффективной хозяйственной деятельности. Данная трактовка сущности и последствий глобализации в настоящее время требует уточнения, что обусловлено появлением новых аспектов данного явления под влиянием текущего глобального кризиса. При этом оценка характера и глубины кризисных явлений с учетом новой траектории глобализационных процессов является фундаментальной задачей для оценки его долгосрочного воздействия на состояние мирового хозяйства и выработки эффективных антикризисных стратегий.

В второй половине XX века миропорядок, трактуемый как геоисторический объект, характеризовался двоичной структурой (Запад/Восток и Север/Юг), построенной на соперничестве двух сверхдержав. Формирование на рубеже XX-XXI веков многополярного мира в результате повышения темпов экономического роста Китая и ряда других государств, реализовавших стратегию догоняющего развития, а также повышение экономического потенциала Европейского Союза привели к реаллокации активов в границах мирового хозяйства. В то же время были пересмотрены традиционные представления о конфигурации экономического цикла в результате трансформации механизма кризиса на рынке недвижимости, возникшего в США, и его превращения в финансовый, экономический, промышленный и социальный. Особенностью указанных кризисных явлений стало приобретение ими геоэкономического и политического характера, что нашло отражение соответственно в быстром распространении на Европу и в неэффективности консервативных и неолиберальных антикризисных программ.

Следствием глобального кризиса становится замещение совокупности равновесий на локальных отраслевых рынках равновесным состоянием на глобальных рынках. При этом изменяется состав субъектов мирохозяйственных 
отношений, который дополняется международными валютно-финансовыми организациями (МВФ, Всемирный Банк и др.) и интегрированными образованиями («Большая семерка» и др.). Одновременно происходит восстановление значимости национальных государственных образований как самостоятельных игроков в международном экономическом пространстве, что приводит к потере актуальности неолиберального дискурса.

Проведение стимулирующей бюджетнофинансовой политики, направленной на восстановление повышательной тенденции развития экономики, обусловливает увеличение глобальной денежной базы, рост бюджетного дефицита и государственного долга стан Организации экономического сотрудничества и развития (ОЭСР), что повышает взаимозависимость ее участников. С другой стороны, наблюдается существенный рост резервов в государствах с развивающейся рыночной экономикой и в странахэкспортерах (Китай, страны Персидского залива и др.), где они управляются национальными фондами. В структуре ВВП этих государств увеличивается удельный вес сферы производства, развивается инфраструктурный комплекс и активно применяются инструменты финансового рынка. Последнее способствует превращению Китая из должника в одного из основных кредиторов на внешнем рынке.

В обрабатывающем секторе экономики в период с 2002 по 2010 годы число занятых в США сократилось на 25 проц., в Великобритании - на 27 проц. и в зоне Европейского союза - на 10 проц. [7], в то время как государства с развивающимся рынком (Бразилия, Индия, Китай, страны Южной Африки) становятся ведущими промышленными державами, самодостаточность которых позволят сделать вывод о формировании множественности «полюсов» развития в международном экономическом пространстве при углублении интеграционных процессов. Тем самым, в начале XXI века была подтверждена гипотеза о противоречивости процессов глобализации, которые сопровождаются кардинальным изменением структуры производства и занятости во всех странах, активизацией интеграционных процессов между развитыми странами как значимого фактора накопления конкурентного потенциала производителей и территорий их размещения, ростом рентных доходов добывающих компаний, связанных с устойчивостью цен на энергоносители и неэластичностью спроса на них, а также повышением дифференциации между центром, периферией и полупериферийными территориями. Аналогичные процессы наблюдаются в современном мире, характеризующемся кризисными явлениями, вызванными распространением коронавируса.

В этих условиях одним из источников поступательной макроэкономической динамики, сопровождающейся ростом спроса на трудовые ресурсы, выступает демографический фактор. Согласно данным Международного валютного фонда (МВФ), в настоящее время более $50 \mathrm{Mлн.}$ активного населения ежегодно вступает на глобальный рынок труда. В период с 1980 по 2020 годы численность трудоспособного населения в мире увеличилась на 1,72 млрд. человек. При этом 93 проц. указанного прироста обеспечивается за счет государств Азии, Африки и Латинской Америки. В 2020 году страны ОЭСР располагают 16,5 проц. общемировой численности трудовых ресурсов, тогда как Индия - 15 проц., Китай 22,5 проц.[5]. В XIX веке изменение соотношения между государствами по численности трудоспособного населения в пользу европейских государств стало одной из причин колониальной политики и эмиграции. В настоящее время неприменимость инструментов демографической политики эпохи Нового времени обусловливает необходимость поиска новых приемов управления миграционными потоками во взаимозависимом мире [7]. С одной стороны, трудовые ресурсы составляют один из существенных источников поступательной макроэкономической динамики, с другой стороны, растущие барьеры для получения профессиональных и общекультурных компетенций на рынке образовательных услуг, научно-технический прогресс и недостаточная эффективность инструментов государственного регулирования рынка труда ограничивают возможности накопления и эффективной реализации человеческого капитала в развивающихся странах.

Данные МВФ показывают, что в период с 2009 по 2015 годы уровень дифференциации между развитыми и развивающимися странами уменьшился. Это нашло отражение в снижении доли первых в мировом ВВП с 69 до 61 проц. в долларовом эквиваленте и с 53,8 проц. до 47,8 проц. по паритету покупательной способности валют. При этом развитые страны за период с 1999 по 2019 годы обеспечили только 27,5 проц. 
прироста мирового ВВП, их доля в мировой экономике снизилась с 60 до 43 проц. (в долл. США) [5]. Все это свидетельствует о кардинальных изменениях глобального геоэкономического и геополитического равновесия, при этом проведенное исследование позволяет прогнозировать ускорение подобных процессов в будущем.

Следует учитывать роль новых государствлидеров, прежде всего, Китая и Индии, не только в формировании совокупного предложения, но и совокупного спроса. Несмотря на то, что объем потребительских расходов населения Китая уступает аналогичным показателям США, динамика спроса со стороны китайских производителей на сырьевые товары оказывает существенное воздействие на конъюнктуру мировых рынков [7]. Трансформация структуры промышленного производства в Китае, ориентация производителей на использование достижений науки и техники для повышения конкурентоспособности товаров на внешнем рынке и др. делает их привлекательными для иностранных инвесторов. Так, например, согласно данным МВФ, в период с 1993 по 2015 годы потребление нефти и нефтепродуктов развивающимися странами увеличилось на 9 проц., алюминия - на 26,6 проц., меди - на 26,8 проц.[5] Анализ статистических данных показывает, что эти государства оказывают решающее влияние на динамику цен на мировых рынках сырья.

Таким образом, кризисные явления, наблюдаемые во всех странах мира в настоящее время, предопределили необходимость глубоких переосмыслений условий достижения глобального геополитического и геоэкономического равновесия с учетом нового этапа реализации глобализационных процессов. При всем многообразии трактовок последних исследователи рассматривают в качестве их атрибутивной характеристики усиление взаимозависимости участников мирохозяйственных отношений, что выступает источником синергетического эффекта взаимодействия субъектов хозяйствования и территорий их размещения, а также дополнительным фактором их конкурентного потенциала. Однако кризисные явления 2008-2009 гг. и современный кризис показал двойственность глобализационных процессов, проявляющуюся в противоречивых последствиях интеграции и локализации. Одновременно изменяется конфигурация мирового экономического пространства, которое становится многополярным. Традиционное противостояние Центра и периферии замещается конкурентным сотрудничеством между государствами Центра, полупериферии и периферии. Все это обусловливает необходимость пересмотра факторов, определяющих выбор территории размещения производства, включающих новые энергетические ограничения, растущие затраты на оплату труда и необходимость формирования действенных систем технологической безопасности и др. В этих условиях растущую роль играют процессы деглобализации, которые находят выражение в растущей геоэкономической автономии государств Азии и в формировании новых связей между ними и государствами Африки, Латинской Америки.

Учет противоречивых процессов глобализации мирового хозяйства является объективной предпосылкой формирования стратегии долгосрочного развития современной российской экономики, обеспечения конкурентоспособности отечественных производителей на мировых рынках факторов производства и конечных товаров. Понимание тенденций глобализации позволяет сформулировать приоритетные направления развития научных исследований и определить точки промышленного роста, а также избежать угроз, связанных с углублением международного разделения труда.

\section{Библиографический список}

1. Бек У. Что такое глобализация/ Пер. с нем.А.Григорьева и А. Седельника; общ. ред. и послесловие А. Филиппова. М.: Прогресс-Традиция, 2001. 304 с.

2. Ильин М.В., Цымбурский В.Л. Открытое общество: от метафоры к её политической рационализации (исходный миф и его самокритика). М.: МОНФ, 1997

3. Кастельс М. Информационная эпоха: экономика, общество и культура: Пер. с англ. под науч. ред. О.И.Шкаратана. М.: ГУ ВШЭ, 2000. 608 с.

4. Несбит Д. Мегатренды. [Пер. с англ. М. Б. Левина]. М.: АСТ, 2003. 
5. Официальный сайт Международного валютного фонда [Электронный ресурс] Режим доступа: https:// www.imf.org/ru/Search\#q=\%D1\%81\%D1\%82\%D0\%B0\%D1\%82\%D0\%B8\%D1\%81\%D1\%82\%D0\%B8\%D0\%BA\%D0 \%B0\%20\%D0\%B2\%D0\%B2\%D0\%BF \&sort=relevancy

6. Хоффман С. Столкновение глобализаций// Россия в глобальной политике. 2003. Т.1. № 1. 2003. С.78-91.

7. Carroué L. Mondalisation et localisation des activités économiques: les nouveaux défis posés par l’entrée dans le XXI scècle//Des facteurs de changement 2. Territoires 2040. № 6.

8. Robertson R. Globalization: Social Theory and Global Culture. London, 1992.

9. Therborn G. Globalizations: Dimensions, Historical Waves, Regional Effects, Normative Governance // International Sociology. 2000. № 2 .

10. Wallerstein I. World-Systems Analysis// Social Theory Today/ Ed.by A. Giddens \& J.H. Turner. Cambridge: Polity Press,1987. P.309-324.

11. Williamson J. G. Globalization and Inequality, Past and Present // The World Bank Research Observer, 1997, 12(2) (August). P. 117-35. 